\title{
Larval form of the genus Thubunaea Seurat, 1914 from the body cavity of an insect, Supella sp., at M eerut (U.P.), India
}

\author{
H.S. Singh*, M alti and Anshu Chaudhary \\ Department of Zoology, C. C. S. University, Meerut (U.P.), INDIA \\ *Corresponding author. E-mail: hirdaya_singh@rediffmail.com
}

\begin{abstract}
The present communication deals with a larval nematode belonging to the genus Thubunaea Seurat, 1914, from the body cavity of an insect, Supella sp., at Meerut, U.P. Both encysted and free larval stages were recovered. Morphology of the larvae is described in detail.
\end{abstract}

Keywords: Thubunaea, Supella, Larval nematode

\section{INTRODUCTION}

During the course of study of insect parasitic nematodes of Meerut, writers came across two specimens of Supella sp., infected with some cyst and a few free larval forms of varying sizes. The site of infection being body cavity of insect. On detail morphological examination, it was found to be the third larval stage of the genus Thubunaea Seurat, 1914, which has also been once described by Basir, 1948 from Gymnogryllus erythrocephalus at Aligarh. Moreover, earlier adults of this genus has been described by the workers like Goldberg et al. (2002); Goldberg et al., (2003); José Pérez et al., (2007); Goldberg and Bursey (2009); Goldberg and Bursey (2010) and Ávila and Silva (2010).The larvae at disposal of the authors besides being a new host record, exhibits minor variations thus, briefly redescribed as such as the probable larval form of T. grayiacola Sandground, 1933.

\section{MATERIALS AND METHODS}

Supella sp. was collected from kitchen and stores from different localities of Meerut. The specimens were brought to the laboratory and identified with the help of classical works of Imms (1960) and Davies (1977). The insects were anaesthetized with the help of Chloroform. Subsequently, a thorough examination of their alimentary canal and the whole body was made under stereoscopic binocular microscope. The nematode parasites were picked up with the help of fine glass dropper. After removal from host, the parasites were washed in normal saline and fixed either in A.F.A. fixative or in hot $70 \%$ Alcohol. For the study of morphology, parasites were cleared in Glycerine or Lactophenol. The diagrams were made with the help of Camera Lucida to support the morphological observations.

\section{RESULTS}

No. of host examined-20, No. of host infected - 02, Body length varies from $8.20-10.33 \mathrm{~mm}$. Lateral alae present, extending from head to tip of the tail, about 0.01-0.015 $\mathrm{mm}$ broad. Cuticular striations present. Mouth cavity opens into a vestibule, $0.040-0.042 \mathrm{~mm}$ long. Nerve ring surrounds the middle of the anterior portion of oesophagus about $0.13-0.15 \mathrm{~mm}$ from the anterior end. Excretory pore situated about $0.26-0.30 \mathrm{~mm}$ from anterior end. Oesophagus occupies a length of about one fourth of the body, being $2.62-2.72 \mathrm{~mm}$ long. It is divisible into two distinct parts, a short anterior part, $0.24-0.26 \mathrm{~mm}$ long and $0.038-0.042 \mathrm{~mm}$ broad, followed by a long posterior part, measuring 2.32-2.35 and 0.018-0.20 mm. Anterior part of the oesophagus is muscular in anterior portion and glandular in posterior portion while, the posterior part of the oesophagus is completely muscularised. Intestine well developed. It has an average width about 0.10-0.12 $\mathrm{mm}$. Posteriorly, it communicates with a short and narrow rectum, which is more or less hidden by the surrounding rectal glands. Three rectal glands present. All rectal glands are nearly of the same size. Anus situated about $0.14-0.16 \mathrm{~mm}$ from the posterior end. Tail conoid in form. Caudal papillae absent. Sexes can be easily differentiated in these larvae. The females have already developed a complete outline of the reproductive apparatus. The position of vulva is not very clear. Uteri two. These extend posteriorly as ovaries, which run parallel to each other. Male larvae can be easily distinguished from the female larvae by the form of reproductive apparatus. Testis, developed extending upto the $2 / 3$ part of the body.

Some cysts were also found in the body cavity of the insect. The wall of the cyst is membranous and its major portion is filled with the coils of larva, the cysts are nearly spherical in form and very in size being $1.89-1.90 \mathrm{~mm}$ in 
diameter. Larvae in cyst form about three-and a-half coils. Cysts were lying free in the body cavity of the host. There appears to be no morphological differences between the free larvae and those, which are found, encysted. Even the reproductive apparatus has developed to the same stage in both (Table 1, Plates I and II).

\section{DISCUSSION}

Teeth pattern on lips and form of the stoma enables us to place these larvae in the family Physalopteridae which is characterized by having asymmetrical lips. This family has been represented with only two genera viz., Thubunaea Seurat, 1914 and Physalopteroides Wu and
Liu, 1940. Basir (1948) doubted the establishment of the genus Physalopteroides Wu and Liu, 1940, with which we also agree. Most important feature of the genus Thubunaea Seurat, 1914 is its characteristic vestibule which has also been advocated by Basir (1948). To the best of our knowledge, genus Thubunaea Seurat, 1914 has eleven species in all. Out of which five are with asymmetrical lips viz., T. asymmetrica Baylis, 1930; T. agamae Sandground, 1933; T. grayiacola Sandground, 1933, T. dactyluris Karve, 1938 and T. impar Malan, 1939. Earlier, Basir, 1948 described the larvae of T. impar from the body cavity of Gymnogryllus erythrocephalus at Aligarh. The present larvae come closest to T. grayiacola,

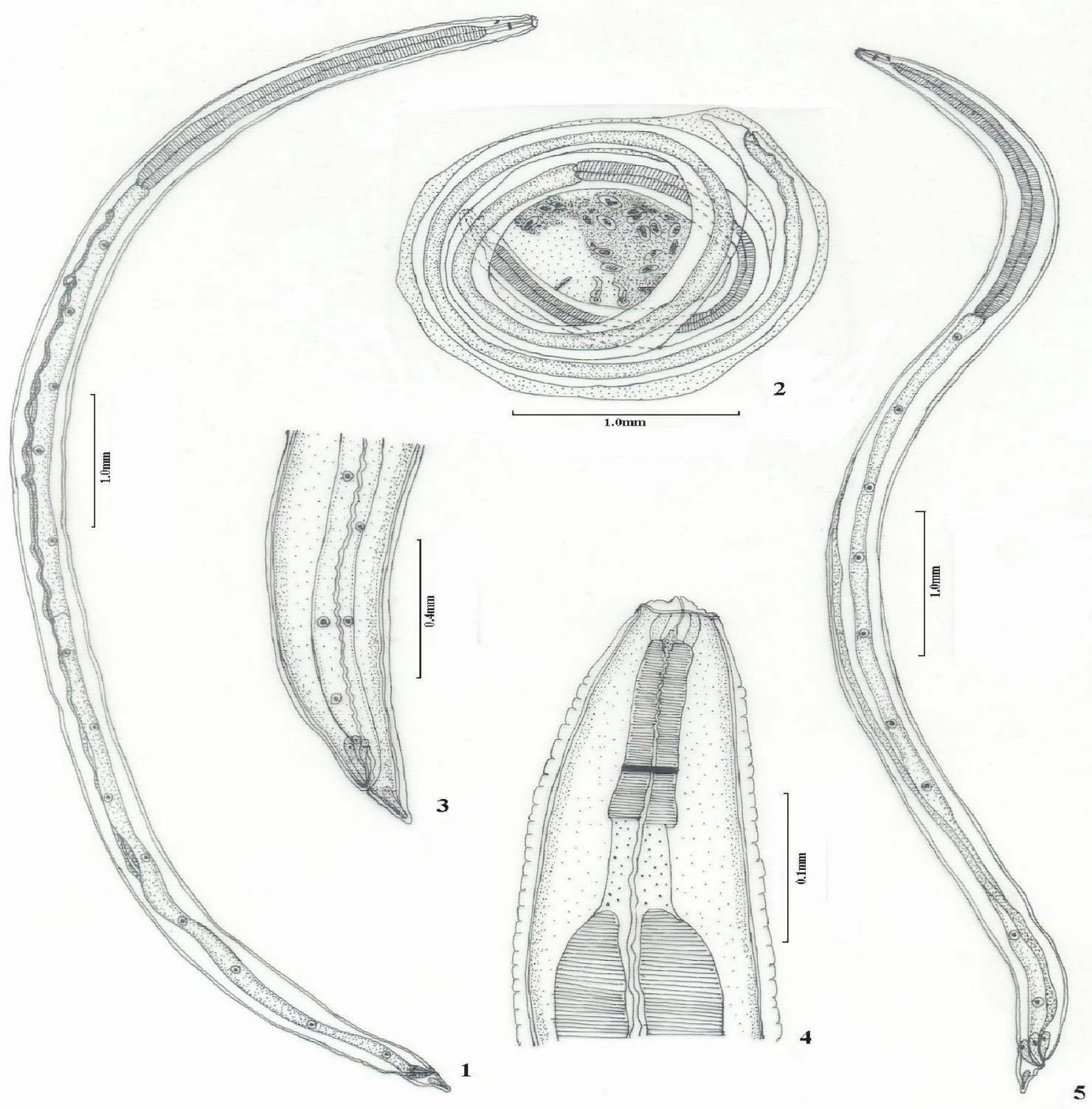

Platel. Thubunaea impar Basir, 1941 Figs. 1-5. 1) F ree larva (female), entire, lateral view, 2) Encysted larva, entire, 3) Posterior region, enlarged, 4) Anterior region, enlarged, 5) F ree larva (male), entire, lateral view. 

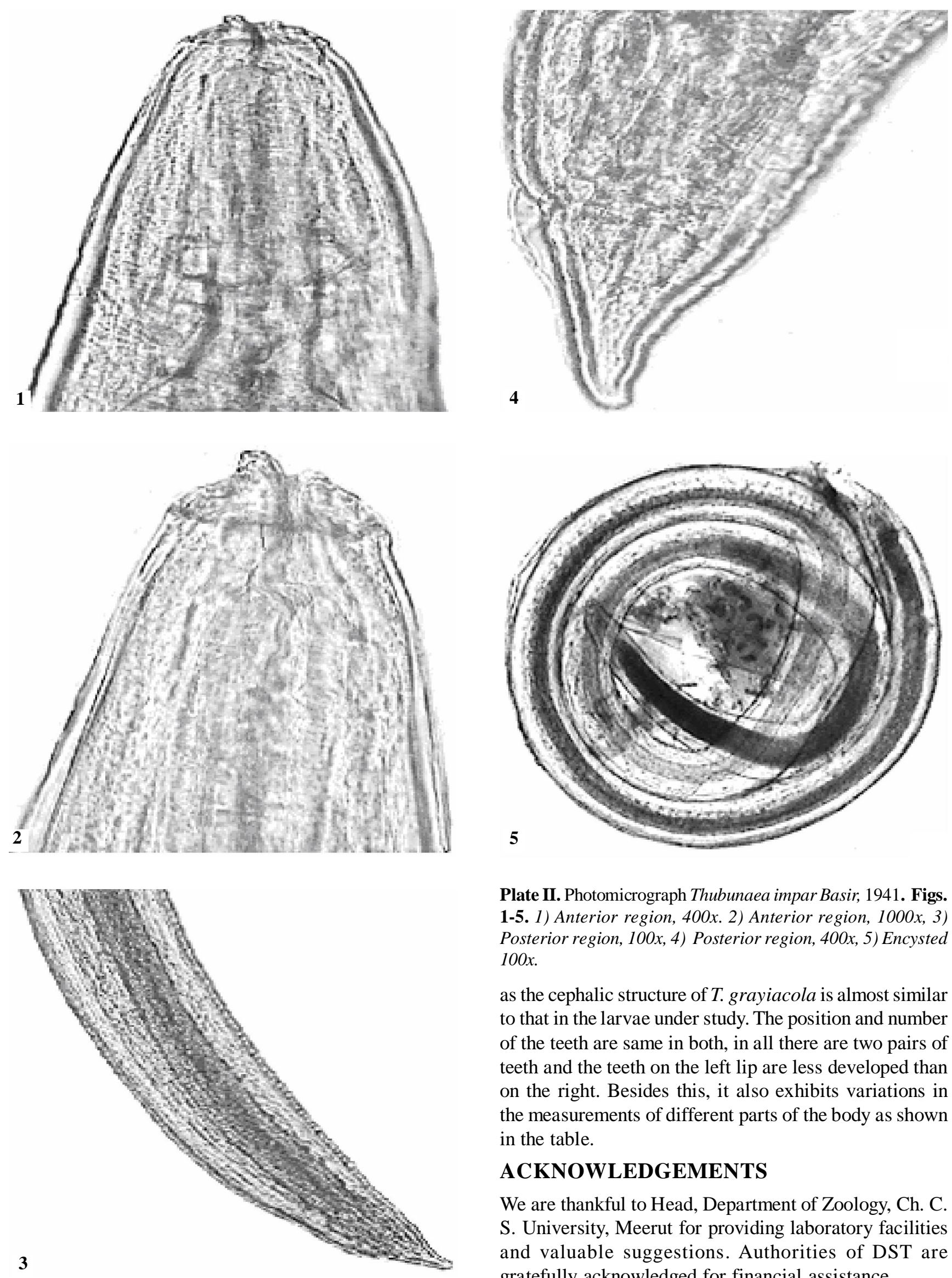

Platell. Photomicrograph Thubunaea impar Basir, 1941. Figs 1-5. 1) Anterior region, 400x. 2) Anterior region, 1000x, 3) Posterior region, 100x, 4) Posterior region, 400x, 5) Encysted $100 x$.

as the cephalic structure of T. grayiacola is almost similar to that in the larvae under study. The position and number of the teeth are same in both, in all there are two pairs of teeth and the teeth on the left lip are less developed than on the right. Besides this, it also exhibits variations in the measurements of different parts of the body as shown in the table.

\section{ACKNOW LEDGEMENTS}

We are thankful to Head, Department of Zoology, Ch. C. S. University, Meerut for providing laboratory facilities and valuable suggestions. Authorities of DST are gratefully acknowledged for financial assistance. 
Table 1. Showing measurement of various body parts of the larval forms of the genus Thubunaea Seurat, 1914.

\begin{tabular}{|c|c|c|}
\hline & $\begin{array}{c}\text { Larvae of T. impar described } \\
\text { by Basir, } 1948\end{array}$ & Present worm \\
\hline Host & Gymnogryllus erythrocephalus & Supella sp. \\
\hline Habitat & Body cavity & Body cavity \\
\hline Locality & Aligarh & Meerut \\
\hline Body length & $6.00-8.30 \mathrm{~mm}$. & $8.20-10.33 \mathrm{~mm}$ \\
\hline Body width & - & $0.30-0.32 \mathrm{~mm}$ \\
\hline Alae width & $5.3-7.0$ & $0.010-0.015 \mathrm{~mm}$ \\
\hline Length of mouth cavity & 22 & $0.040-0.042 \mathrm{~mm}$. \\
\hline Teeth & Three pairs & Two pairs \\
\hline Oesophagus length & $1.85-2.07 \mathrm{~mm}$. & $2.62-2.72 \mathrm{~mm}$. \\
\hline $1^{\text {st }}$ part of oesophagus & $225-240 \times 25-30$ & $0.24-0.26 \times 0.038-0.042 \mathrm{~mm}$. \\
\hline $2^{\text {nd }}$ part of oesophagus & $1.62-1.83$ & $2.32-2.35 \times 0.18-0.20 \mathrm{~mm}$ \\
\hline Nerve ring from anterior end & 130 & $0.13-0.15 \mathrm{~mm}$ \\
\hline Excretory pore behind the nerve ring & 40 & $0.11-0.13 \mathrm{~mm}$. \\
\hline Intestine width & 70 & $0.10-0.12 \mathrm{~mm}$. \\
\hline Rectum length & 80 & $0.21-0.22 \mathrm{~mm}$. \\
\hline No. of rectal glands & Three & Three \\
\hline Anus from the posterior end & $150-170$ & $0.14-0.16 \mathrm{~mm}$. \\
\hline
\end{tabular}

\section{REFERENCES}

Ávila, R.W. and Silva, R.J. (2010). Checklist of helminths from lizards and amphibaenians (Reptilia, Squamata) of South America. J . Venom. Anim. Toxins incl. Trop. D is, 16: 543572.

Basir, M.A.(1948). On a larval nematode from an insect with a note on the genera Thubunaea Seurat, 1914 and Physalopteroides Wu and Liu, 1940. The J ournal of Parasitology, 301-305.

Baylis, H.A. (1930). A third species of the nematode genus Thubunaea. Ann. and M ag. Nat. Hist., Ser. 10. 5: 246-249.

Davies, R.G. (1977). Imms G eneral Textbook of Entomology, Champam and Hall, NewYork.

Goldberg, S.R., Bursey, C.R. and Beaman, K.R. (2002).Gastrointestinal nematodes of the Isla Cerralvo Spiny Lizard, Sceloporus grandaevus (Phrynosomatidae) from Baja California Sur, Mexico. M exico Bulletin (Southern California Academy of Sciences), December 2002.

Goldberg, S.R., Bursey, C.R. and Camarillo-Rangel, J.L. (2003). Gastrointestinal helminths of seven species of Sceloporine lizards from Mexico. The Southwestern Naturalist 48: 208217.

Goldberg, S.R. and Bursey, C.R. (2009). Helminths from seven species of M icrolophus (Squamata: Tropiduridae) from Peru.
Salamandra 45: 125-128.

Goldberg, S.R. and Bursey, C.R. (2010). Helminths from Eight Species of African Skinks (Trachylepis: Scincidae) Comparative Parasitology 77: 236-241.

Imms, A.D. (1960). A general text book of entomology, Methuen, London.

José Pérez, Z., Balta, K., Salizar, P. and Sánchez, L. (2007). Nematofauna of three species of lizards (Sauria: Tropiduridae and Gekkonidae) from National Reserve Paracas, Ica, Peru. Rev. peru. biol. 14: 43- 045 .

Karve, J.N. (1938). Some nematode parasites of lizards. Livro Jubilar Travassos, 251-258.

Malan, J.R. (1939). Some helminths of South African lizards. Onderstepoort J ournal of Veterinary Science and An. Indust. 12: 21-74.

Sandground, J.H. (1933). Reports on the Scientific Results of an Expedition to the South-western Highlands of Tanganayika Territory. VI. Parasitic nematodes from East Africa and Southern Rhodesia. Bull. M us. Comp. Zool. 75: 263-293.

Seurat, L.G. (1914). Sur un nouveau nematode parasite des reptiles. C.R. Soc. Biol., 76 (Pt.1): 724-727.

Wu, H.W. and Liu, C.K. (1940). Helminthologic notes, II. Sinensia 11: 397 